Article

\title{
Application of Refined Kano's Model to Shoe Production and Consumer Satisfaction Assessment
}

\author{
Chi-Hung Lo (1)
}

Citation: Lo, C.-H. Application of Refined Kano's Model to Shoe Production and Consumer Satisfaction Assessment. Sustainability 2021, 13, 2484. https://doi.org/10.3390/su13052484

Academic Editor: Flavio Boccia

Received: 1 February 2021

Accepted: 19 February 2021

Published: 25 February 2021

Publisher's Note: MDPI stays neutral with regard to jurisdictional claims in published maps and institutional affiliations.

Copyright: (C) 2021 by the author. Licensee MDPI, Basel, Switzerland. This article is an open access article distributed under the terms and conditions of the Creative Commons Attribution (CC BY) license (https:/ / creativecommons.org/licenses/by/ $4.0 /)$.
Department of Industrial Design, Tunghai University, Taichung 407224, Taiwan; chlo@thu.edu.tw

\begin{abstract}
Many industries are labor-intensive and energy- and resource-consuming. A sustainable development plan is necessary for the industries as industrial structures have been changing recently. Taiwan's shoe industry also has experienced such changes and requires a sustainable product development plan for continuous development. Therefore, this study aims to propose a new method by introducing a model of sustainable product development to facilitate the sustainable development of the industry. By taking air-cushioned casual shoe production as an example, this study suggested the refined Kano quality model for exploring the product attributes that improved the customers' satisfaction. The refined Kano model that was established with interviews and questionnaire surveys was effective to define the product attributes that contributed to satisfying the customers and understanding their perception of product attributes. In the air-cushioned casual shoe production, the model found function, design, innovation, marketing, and service to be important for manufacturers to develop products with limited. It also suggested the priority be put on the attributes of high value-added quality, key quality, and potential quality. The model helped manufacturers decide which product attributes they need to invest in and develop. The relation of product attributes and consumer satisfaction for a sustainable product development model was also found by using the refined Kano model. The result of this study is expected to apply to various industries for establishing an appropriate sustainable product development model.
\end{abstract}

Keywords: product attributes; Kano quality model; refined Kano quality model; sustainable product development; consumer satisfaction

\section{Introduction}

Sustainable product development (SPD) refers to a method for enabling sustainable planning and developing products with a framework for strategic sustainable development (FSSD) or the natural step (TNS) framework especially in the early stage of product design [1-3]. As the demand for environment-friendly products and the related regulations increase, sustainability in product development becomes critical [4]. Ishioka and Yasuda [5] proposed three factors to define the strategies of SPD: performance, attractiveness, and competitiveness. However, the concept of SPD still needs clear definitions in industries. A "good" brand created from good SPD is identified and differentiated with the products and creates the consumers' loyalty. The brand and products need to be in accordance to obtain the consumer's trust. Thus, the products prolong their life cycles through upcycling, recycling for sustainability development, which is an example of a well-managed brand.

Well-managed brands help the manufacturers and related industries increase revenues through price competitiveness. Therefore, governments encourage companies to develop their brands for the global market, which raises countries' recognition. The creation and promotion of brands have become key factors in industries. Park et al. argued that brands have a "life cycle" that comprises introduction, refinement, and consolidation. Each period demands a different development strategy, and eventually, the strategies in a life cycle must be harmonized to last for a long time [6]. Richardson et al. [7] mentioned that a brand image is an external clue for consumers to evaluate the product quality. Reynolds and 
Gutman [8] used the Means-End Chain method to define a brand image with a serial chain of product attributes and individual values. Hsu [9] argued that product attributes have a direct impact on consumers' willingness to purchase through evaluating how innovative products are. Anderson and Sullivan [10] investigated the causes and consequences of customer satisfaction, which is found to increase when the quality exceeds the expectations, and it has excessive impact on repurchase intentions. The formation of a brand image throughout a life cycle requires understanding how consumers consider product attributes when choosing brands and products. Consumers try to realize the gains and benefits of products by considering their values. As the main goal of SPD, the gains and benefits are defined as the physical, measurable, abstract, and subjective attributes of a product. Huiskonen and Pirttila [11] found that quality factors have a non-linear relationship with product attributes. In other words, they pointed out that not all consumers experience a linear positive correlation between the product attributes and satisfaction with a product.

Shoes are daily necessities and require functionality as well as fashionable design. At the same time, consumers base their perceptions and values on shoes in terms of sustainability. Thus, a good brand of shoe must satisfy consumers with the quality of functionality and design, and sustainability [12]. Consumer perceptions of a brand image and product attributes affect the evaluation and selection when purchasing shoes, too. However, the conventional shoe industry has wasted so much energy and natural resources, which hinders sustainable development and has not obtained recognition as a good brand from consumers. Therefore, a well-established SPD enables the industry to focus on the product attributes that need to be improved.

This study's purpose is to define SPD for the shoe industry of Taiwan to suggest a way to meet the consumer demand and increase their satisfaction. The Kano two-dimensional model [13] was adopted to define the quality classification of consumer demand for product attributes by refining the Kano model by referring to Yang's result [14] for minimizing the weakness of the original Kano model. For an SPD plan for the shoe industry, consumer preference of the quality and sustainability were considered, which provides the industry with accurate information for establishing marketing strategies and obtaining consumer loyalty. The result of this study, thus, presents a new method for establishing a SPD for the shoe industry.

\section{Theoretical Background}

\subsection{Kano's Two-Dimensional Model}

The Kano two-dimensional model was proposed by Kano et al. [10] and used the Motivator-Hygiene theory (M-H theory) by Herzberg, which introduced the quality-related field and the "M-H property of quality." A Kano model includes the following five qualities.

(1) "Attractive Quality" as a tool to create product differentiation;

(2) "One-dimensional Quality" as a standard for product grading to match consumer satisfaction and product price;

(3) "Must-be Quality" as a basic accessory to a product. Only product accessories at lower costs prevent any form of waste by devoting excessively high costs to the must-be quality element;

(4) "Indifferent Quality" as the minimum level of quality for consumers to accept after comparing to other products;

(5) "Reverse Quality" as a high degree of product and service achievement resulting in dissatisfaction and a low degree of product.

Different needs and performances are defined by the relationship between quality attributes and consumer satisfaction. In the model, the horizontal coordinate indicates the fulfillment of the quality attributes, while the vertical coordinate indicates consumer satisfaction (Figure 1). The quality attributes are classified into five major categories according to the relation of the quality and satisfaction. 


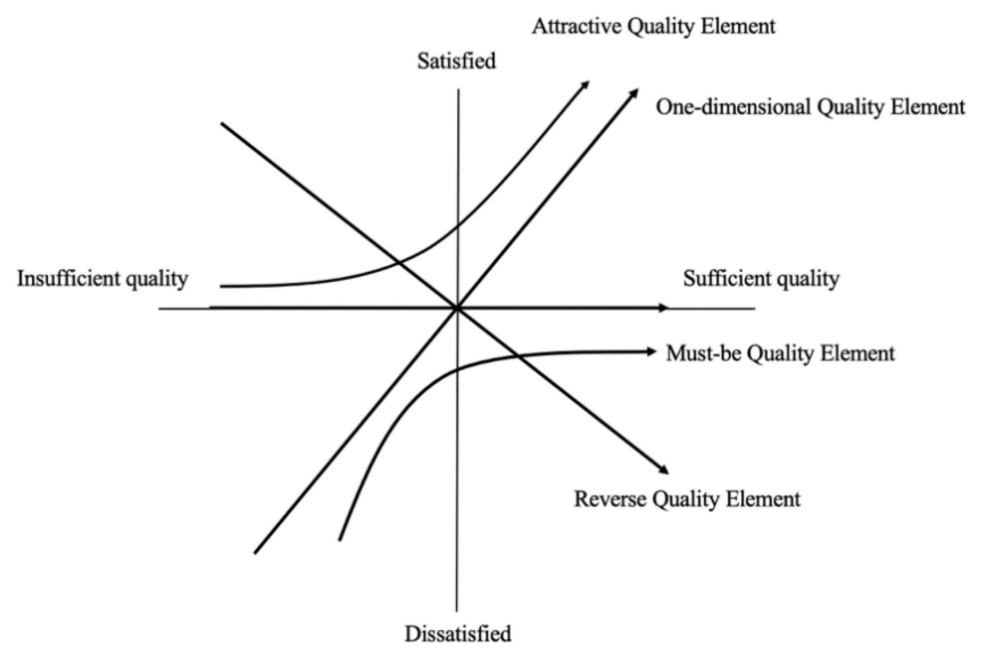

Figure 1. The Kano two-dimensional model.

In the model, Kano proposed the life cycle of the attractive quality as follows: indifferent quality $\rightarrow$ attractive quality $\rightarrow$ one-dimensional quality $\rightarrow$ must-be quality. By assuming that other attributes are equally influential, a product or service with sufficient attractive quality would attract consumers and thus create a competitive advantage. Despite the attractive quality being at the highest level of quality satisfaction, it evolves into the one-dimensional quality and must-be quality as a result of competition with other products [15]. The evolution of the life cycle starts from the indifferent quality, which becomes the attractive quality after a certain time. Therefore, manufacturers must decide whether they should abandon the indifferent quality perceived by the consumers.

\subsection{Advantages of Kano's Two-Dimensional Model}

The traditional way to measure consumer satisfaction is to determine the satisfaction of consumers with one-dimensional quality. Jane and Dominguez [16] argued that the Kano model is not only theoretical but also practical. As different from other general theories that explore consumer preferences, the Kano model focuses on consumer expectations and the attributes that affect consumer satisfaction. The Kano two-dimensional quality model especially provides service quality attributes precisely. Classified service quality attributes reveal the needs of different consumers simply and clearly. Kano's two-dimensional quality model gets rid of the false idea of "no complaint means consumer satisfaction" and helps employees set priorities for their work [16-19]. Quality with the largest impact brings consumer satisfaction to the next level by defining the consumer's requirement for the product, which allows the product developer to find the most prioritized project. The improvement of one-dimensional and attractive quality has a larger impact on consumer satisfaction than must-be quality. Different demands exist in the attractive quality, onedimensional quality, and must-be quality segment services and solutions. Therefore, Kano's two-dimensional quality model provides effective guidelines on how to impact consumer satisfaction. Kano's two-dimensional quality model also forms a competitive strategy for quality differentiation.

\subsection{Classification of Kano's Two-Dimensional Model}

By using Kano's two-dimensional quality model, researchers have different classification methods to assess consumer feelings and satisfaction according to quality attributes. The quality attributes are classified with consumers' responses. The various classification methods were proposed with the cross-reference of the consumer's options as following.

(1) Noriaki proposed the six grade evaluation ("satisfied," "must-have," "irrelevant," "unsolvable," "dissatisfied," and "others") based on two-dimensional quality attributes as provided in Table 1 [13]. 
(2) Schvaneveldt proposed ("like," "as expected," "of no impact," "of no help," and "dislike") to evaluate consumer expectations with two-dimensional quality attributes [20].

(3) Matzler and Hinterhuber proposed the five grade evaluation ("like," "take for granted," "indifferent," "tolerable," and "dislike") to evaluate consumer expectations [21].

In this study, the classification method by Matzler and Hinterhuber [21] was used to analyze Kano's two-dimensional quality model.

Table 1. Kano's two-dimensional quality evaluation [13].

\begin{tabular}{|c|c|c|c|c|c|c|}
\hline $\begin{array}{ll}\text { Insufficient } \\
\text { Sufficient }\end{array}$ & Satisfied & Must-Have & Indifferent & Unsolvable & Dissatisfied & Others \\
\hline Satisfied & $\begin{array}{l}\text { Cannot Be } \\
\text { Evaluated }\end{array}$ & $\begin{array}{l}\text { Attractive } \\
\text { Quality }\end{array}$ & $\begin{array}{l}\text { Attractive } \\
\text { Quality }\end{array}$ & $\begin{array}{l}\text { Attractive } \\
\text { Quality }\end{array}$ & $\begin{array}{c}\text { One- } \\
\text { dimensional } \\
\text { Quality }\end{array}$ & $\begin{array}{l}\text { Other } \\
\text { Quality }\end{array}$ \\
\hline Must-Have & $\begin{array}{l}\text { Reverse } \\
\text { Quality }\end{array}$ & $\begin{array}{l}\text { Indifferent } \\
\text { Quality }\end{array}$ & $\begin{array}{l}\text { Indifferent } \\
\text { Quality }\end{array}$ & $\begin{array}{l}\text { Indifferent } \\
\text { Quality }\end{array}$ & $\begin{array}{l}\text { Must-Be } \\
\text { Quality }\end{array}$ & $\begin{array}{l}\text { Other } \\
\text { Quality }\end{array}$ \\
\hline Indifferent & $\begin{array}{l}\text { Reverse } \\
\text { Quality }\end{array}$ & $\begin{array}{l}\text { Indifferent } \\
\text { Quality }\end{array}$ & $\begin{array}{l}\text { Indifferent } \\
\text { Quality }\end{array}$ & $\begin{array}{l}\text { Indifferent } \\
\text { Quality }\end{array}$ & $\begin{array}{l}\text { Must-Be } \\
\text { Quality }\end{array}$ & $\begin{array}{l}\text { Other } \\
\text { Quality }\end{array}$ \\
\hline Unsolvable & $\begin{array}{l}\text { Reverse } \\
\text { Quality }\end{array}$ & $\begin{array}{l}\text { Indifferent } \\
\text { Quality }\end{array}$ & $\begin{array}{l}\text { Indifferent } \\
\text { Quality }\end{array}$ & $\begin{array}{l}\text { Indifferent } \\
\text { Quality }\end{array}$ & $\begin{array}{l}\text { Must-Be } \\
\text { Quality }\end{array}$ & $\begin{array}{l}\text { Other } \\
\text { Quality }\end{array}$ \\
\hline Dissatisfied & $\begin{array}{l}\text { Reverse } \\
\text { Quality }\end{array}$ & $\begin{array}{l}\text { Reverse } \\
\text { Quality }\end{array}$ & $\begin{array}{l}\text { Reverse } \\
\text { Quality }\end{array}$ & $\begin{array}{l}\text { Reverse } \\
\text { Quality }\end{array}$ & $\begin{array}{l}\text { Cannot Be } \\
\text { Evaluated }\end{array}$ & $\begin{array}{l}\text { Other } \\
\text { Quality }\end{array}$ \\
\hline Others & $\begin{array}{l}\text { Other } \\
\text { Quality }\end{array}$ & $\begin{array}{l}\text { Other } \\
\text { Quality }\end{array}$ & $\begin{array}{l}\text { Other } \\
\text { Quality }\end{array}$ & $\begin{array}{l}\text { Other } \\
\text { Quality }\end{array}$ & $\begin{array}{l}\text { Other } \\
\text { Quality }\end{array}$ & $\begin{array}{l}\text { Other } \\
\text { Quality }\end{array}$ \\
\hline
\end{tabular}

A questionnaire based on Kano's two-dimensional quality evaluation comprised the sets of positive and negative questions to evaluate the responses for product attributes (Table 2). The questions cross-classified the respondents' requirements for the quality attributes. The level of satisfaction or dissatisfaction with the quality attributes was evaluated with the coefficients of satisfaction and dissatisfaction.

Table 2. An example of questionnaire options in Kano's two-dimensional model.

\begin{tabular}{ll}
\hline & Question $\mathbf{1}$ \\
\hline \multicolumn{1}{c}{ Air-cushioned casual shoes should "come } & Air-cushioned casual shoes should not "come \\
with" a warranty period. What do you think? & with" a warranty period. What do you think? \\
\hline$\square$ Like & $\square$ Like \\
$\square$ Take for granted & $\square$ Take for granted \\
$\square$ Indifferent & $\square$ Indifferent \\
$\square$ Acceptable & $\square$ Acceptable \\
$\square$ Dislike & $\square$ Dislike \\
\hline
\end{tabular}

\subsection{Classification by the Refined Kano Two-Dimensional Quality Model}

With Kano's two-dimensional quality model, Yang [11] subdivided the attributes of attractive, one-dimensional, must-be, and indifferent quality into eight sub-elements according to the level of importance (Table 3). After the quality attributes are classified by Kano's two-dimensional quality analysis, Kano's two-dimensional quality classification is refined based on the consumer evaluation. The example of a refined Kano two-dimensional questionnaire is shown in Table 4. 
Table 3. Example of a refined Kano two-dimensional quality model.

\begin{tabular}{ccc}
\hline Classification & Important Attribute & Less Important Attribute \\
\hline Attractive quality & High Attractive Quality & Low Attractive Quality \\
\hline One-dimensional quality & High Value-Added & Low Value-Added \\
\hline Must-be quality & Critical Quality & Required Quality \\
\hline Indifferent quality & Potential Quality & Irrelevant Quality \\
\hline
\end{tabular}

Table 4. Example of refined Kano two-dimensional questionnaire options.

\begin{tabular}{|c|c|c|c|c|c|c|c|c|c|c|}
\hline \multicolumn{11}{|l|}{ Question 1} \\
\hline & \multicolumn{5}{|c|}{ Importance } & \multicolumn{5}{|c|}{ Satisfaction } \\
\hline $\begin{array}{l}\text { Importance: Does the consumer attach great importance to the product attributes } \\
\text { provided by the air-cushioned casual shoes? } \\
\text { Satisfaction: Is the consumer satisfied with the product attributes provided by the } \\
\text { air-cushioned casual shoes? }\end{array}$ & 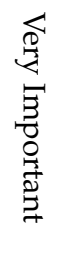 & 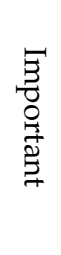 & 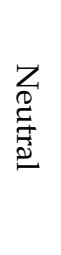 & 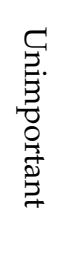 & 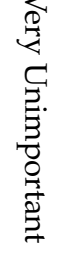 & 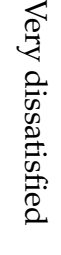 & 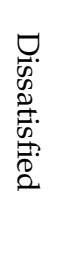 & $\underset{D}{Z}$ & $\begin{array}{l}\infty \\
\stackrel{2}{*} \\
\stackrel{0}{0} \\
\stackrel{0}{\mathscr{0}} \\
\stackrel{0}{2}\end{array}$ & 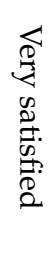 \\
\hline Comfortable and soft to wear & $\square$ & $\square$ & $\square$ & $\square$ & $\square$ & $\bigcirc$ & $\bigcirc$ & 0 & 0 & $\bigcirc$ \\
\hline
\end{tabular}

\subsection{Consumer Satisfaction Coefficient}

To measure consumer demand for product quality, Kano et al. [10] argued that one may start with the unavailable or lacking ratio of attributes of the attractive, linear, and must-be quality. The consumer satisfaction coefficient is used to find out the requirements for product quality. To improve the effectiveness of consumer satisfaction, the attractive and one-dimensional quality need to be evaluated together as follows.

$$
\begin{gathered}
\text { Satisfaction coefficient } C_{S i}=(A+O) /(A+O+M+I) \\
\text { Dissatisfaction coefficient } C_{D i}=(O+M) /(A+O+M+I)(-1)
\end{gathered}
$$

where $\mathrm{A}, \mathrm{O}, \mathrm{M}$, and I are the attributes of the attractive, one-dimensional, must-be, and indifferent quality, respectively. A larger satisfaction coefficient indicates higher consumer satisfaction, while a smaller dissatisfaction coefficient means higher dissatisfaction. Thus, products with higher coefficients need to be prioritized. As high coefficients indicate a better effect of product improvement than low ones, this method analyzes the improvement of a certain quality attribute for improving the quality of product and satisfying consumer demand.

By assuming that $C_{S i}$ and $C_{D i}$ are equally important to consumer satisfaction, the maximum impact coefficient is defined as Equation (3) [22].

$$
C_{i}=\operatorname{Max}\left[\frac{C S_{i}}{\sum_{i}^{m} C S_{i}}, \frac{C D_{i}}{\sum_{i}^{m} C D_{i}}\right]
$$

Based on a questionnaire survey of the Kano model, Lu and Juan [23] proposed a performance indicator of high-quality residence buildings in Taiwan. According to the indicator, they investigated the residents' satisfaction with new residential buildings. By integrating the Kano model and theory of inventive problem-solving (TRIZ), Zhang et al. [24] introduced a Kano-TRIZ industrial design method. Tu and Yang [25] used Kano's twodimensional model to find the quality attributes of hand-touch products. Wu et al. [26] suggested the priorities of product/service improvement through product/service performance monitoring and consumer demand analysis from large-scale online consumers' 
reviews. Chen et al. [27] proposed the combined method of a refined Kano model and the quality function deployment (QFD) method. The refined Kano model was used to understand how consumers perceive service attributes developed based on the Dineserv measurement. Min et al. [28] defined the feature of each part in the Kano model to analyze the dynamics of consumer demand and evaluation as the main indicator of service quality.

\section{Methodology and Procedures}

A company that produces and sells air-cushioned casual shoes in Taiwan was chosen for this study. First, this research interviewed experts to confirm the research framework as the product design and brand of the shoe industry in Taiwan are much diversified. The expert interview was performed to discuss the establishment and adjustment of the product attributes of air-cushioned casual shoes and the statistical method. Then, this research created a questionnaire to evaluate the satisfaction with the brand of the shoes. The main purpose was to establish a refined Kano two-dimensional model for understanding the consumer demand for product quality in a QFD relationship matrix (Figure 2).

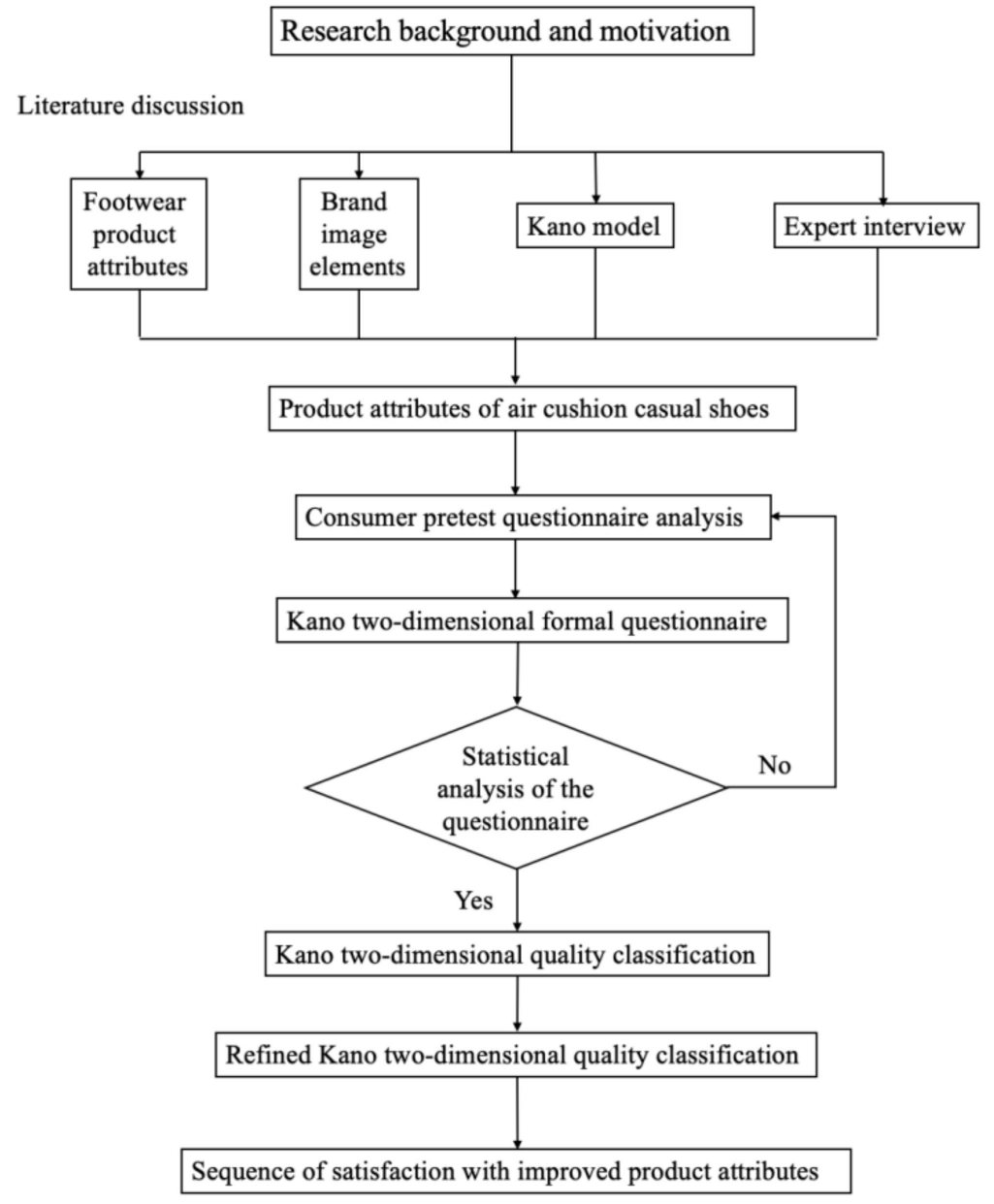

Figure 2. The research framework of the establishment of sustainable product development (SPD) of the air-cushioned casual shoe company in Taiwan.

\subsection{Questionnaire Design}

The purpose of the questionnaire survey was to understand which quality attributes satisfied consumers. The questionnaire was created to have two parts: a pre-test and a formal questionnaire (Figure 3). The quality attributes of air-cushioned casual shoes were determined through the literature review and expert interviews. Based on the responses of the pretest questionnaire, the quality attributes were selected according to the responses of the formal questionnaires. The interviews with experts (Table 5) helped improve the 
validity of the questionnaire structure. As the result, 55 product attributes in four categories were obtained (Tables 6 and 7).

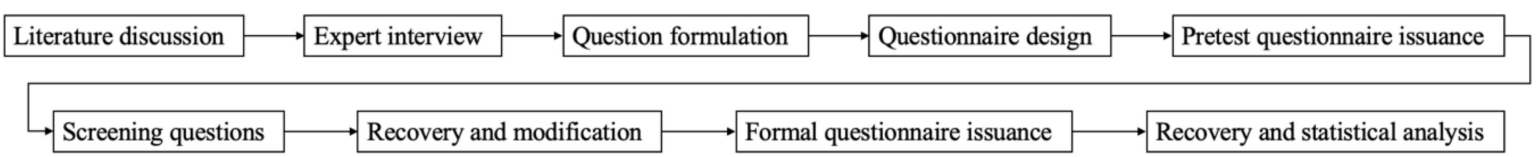

Figure 3. The questionnaire design and implementation of this study.

Table 5. List of experts who were interviewed for selecting product attributes and statistical method.

\begin{tabular}{cccc}
\hline No. & Service Company and Unit & Job Title & Career (Year) \\
\hline 1 & $\begin{array}{c}\text { Shoe design section of Footwear \& Recreation } \\
\text { Technology Research Institute }\end{array}$ & Deputy manager & 5 \\
\hline 2 & $\begin{array}{c}\text { Shoe planning section of Footwear \& Recreation } \\
\text { Technology Research Institute }\end{array}$ & Industry analyst & 4.6 \\
\hline 3 & Assistive device section of Footwear \& Recreation \\
Technology Research Institute & Researcher & 9 \\
\hline 5 & LA NEW & Shop Owner & 1 \\
\hline
\end{tabular}

Table 6. The categories of product attributes and their definitions for air-cushioned casual shoes.

\begin{tabular}{|c|c|c|}
\hline & Categories & Facet Definition \\
\hline 1 & Application and function & $\begin{array}{l}\text { Basic functions and practical and functional features should be } \\
\text { provided for use }\end{array}$ \\
\hline 2 & Innovation and R\&D & Breakthroughs and forward-looking innovations \\
\hline 3 & Brand marketing and service & $\begin{array}{l}\text { Relevant attributes extended from brand marketing and } \\
\text { services }\end{array}$ \\
\hline 4 & Appearance and aesthetic & Presentation of visual appraisal \\
\hline
\end{tabular}

Table 7. The product attributes in each category of air-cushioned casual shoes.

\begin{tabular}{|c|c|}
\hline Categories & Product Attributes \\
\hline \multirow{16}{*}{$\begin{array}{c}\text { Application and } \\
\text { Function } \\
\text { (15 attributes) }\end{array}$} & Size and fitness \\
\hline & Easy to wear and lightweight \\
\hline & Comfortable to wear and softness \\
\hline & Sweat absorption and permeability \\
\hline & Protectiveness and coverage \\
\hline & Air-cushioned flexibility and vibration absorption \\
\hline & Air-cushioned support \\
\hline & Air-cushioned comfort and functionality \\
\hline & $\begin{array}{l}\text { Upper material property and functionality (waterproof, thermostatic, } \\
\text { moisture-wicking) }\end{array}$ \\
\hline & Sole material (anti-slip and abrasion resistant) \\
\hline & Laces, hook and loop fasteners or other adjustments \\
\hline & Suitable for daily activity \\
\hline & Ease of maintenance and care \\
\hline & Durability and service life \\
\hline & Product warranty \\
\hline & Peripheral products (lacing, filler, shoe care kit, etc.) \\
\hline
\end{tabular}


Table 7. Cont.

\begin{tabular}{|c|c|}
\hline Categories & Product Attributes \\
\hline \multirow{11}{*}{$\begin{array}{l}\text { Innovation and } \\
\text { Development } \\
\text { (10 attributes) }\end{array}$} & Innovation and improvement of production technology \\
\hline & Innovation and improvement of style design \\
\hline & $\begin{array}{l}\text { Innovation and improvement of structural design (air-cushioned, outsole, } \\
\text { insole, etc.) }\end{array}$ \\
\hline & Innovation and improvement of air-cushioned technology \\
\hline & Innovation and improvement of material development \\
\hline & Ergonomic \\
\hline & Parts are made of eco-friendly materials \\
\hline & Customization \\
\hline & Fragrant and deodorant \\
\hline & Washable by the washing machine \\
\hline & High twists and turns \\
\hline \multirow{20}{*}{$\begin{array}{l}\text { Brand Marketing } \\
\text { and Service } \\
\text { (21 attributes) }\end{array}$} & Well-known designer or cross-disciplinary cooperation \\
\hline & Topical and full of story \\
\hline & Limited edition \\
\hline & Trademark \\
\hline & Brand awareness \\
\hline & Brand social welfare activities \\
\hline & Product packaging \\
\hline & Product display (window display, model, etc.) \\
\hline & With fashion elements \\
\hline & Made in Taiwan \\
\hline & With department stores and outlets as marketing channel \\
\hline & Service attitude of the shop clerk \\
\hline & Product display at the shop \\
\hline & Image and style of the celebrity endorser \\
\hline & Advertising slogan \\
\hline & Advertising appeals \\
\hline & Advertising frequency and intensity \\
\hline & Pre-sales and post-sales service \\
\hline & Price \\
\hline & Discount or promotional activity \\
\hline \multirow{8}{*}{$\begin{array}{c}\text { Appearance and } \\
\text { aesthetics } \\
\text { (8 attributes) }\end{array}$} & Style (exterior) design \\
\hline & Upper drawing, material matching and design \\
\hline & Style uniqueness \\
\hline & Shoe type and visual effect \\
\hline & Overall coloring \\
\hline & Overall texture (stitches, overflow, etc.) \\
\hline & Handmade \\
\hline & Compatibility with other clothing accessories \\
\hline
\end{tabular}




\subsection{Participants}

3.2.1. Experts

The experts in this study were brand consultants, marketers, or personnel for the development, design, and planning of shoes. The experts were invited from Taiwan External Trade Development Council (TAITRA), Taiwanese brand consulting companies, China Productivity Center, shoe factories, and Footwear \& Recreation Technology Research Institute.

\subsubsection{Consumers}

This study adopted a non-random sampling or purposive sampling approach. The questionnaire survey was performed on- and off-line with customers of stores selling air-cushioned casual shoes.

\section{Results and Analysis}

\subsection{Pre-Test Questionnaire Survey}

The pre-test questionnaire survey was performed from 12-18 May 2019. All participants were consumers who visited stores at Taichung Station, Yizhong Street, Chungyo Department Store, and Taroko Mall. The online questionnaire survey was also performed on the websites of mountain climbing, apparel, men's and women's footwear. A total of 103 valid questionnaires were returned. All responses were processed with SPSS 17.0. In this study, SPSS 17.0 statistical software was used for pre-test questionnaire analysis, and three statistical methods, item analysis, factor analysis and reliability analysis, were used to examine the results of the questionnaire. Item analysis was used to evaluate the decisive value of each item, and Cronbach's $\alpha$ was used to delete non-identifying questions; reliability analysis was designed to increase the confidence of the facet by removing unnecessary questions from each facet.

\subsubsection{Item Analysis}

Item analysis evaluates the critical ratio of each attribute for question deletion. A significance level of $p<0.05$ was a criterion to delete questions. All of the attributes were significant $(p<0.05)$ so that no attribute was deleted.

\subsubsection{Factor Analysis}

The factor analysis result shows the relationship between product categories and attributes. In the principal component analysis, the attributes with a factor load of $>0.5$ were selected. The result showed that 12 out of 55 attributes were deleted: Q1-Size and fitness, Q2-Easy to wear and lightweight, and Q12-Suitable for daily activity in the category of application and functional facet, Q25-Fragrant and deodorant, Q26-Washable by the washing machine, Q27-High twists and turns in the category of innovation and development, Q29-Topical and full of story, Q37-Made in Taiwan, Q45-Pre-sales and post-sales service, Q46-Price, Q47-Discount or promotional activity in the category of appearance and aesthetics facets, and Q54-Handmade in the category of brand marketing and service.

\subsubsection{Reliability Analysis}

Reliability analysis removes the unnecessary attributes from each category for improving the reliability of the analysis. The criterion was a correlation coefficient of $<0.4$ [29]. The deleted attributes included Q24 - Customization and Q23-Parts are made of eco-friendly materials, both in the category of innovation and development. The final reliability was improved from 0.858 to 0.874 . Cronbach's $\alpha$ reached 0.925 .

After the pre-test analysis, the product attribute of the Kano model in this study comprised 41 product attributes in four categories (Figure 4). 


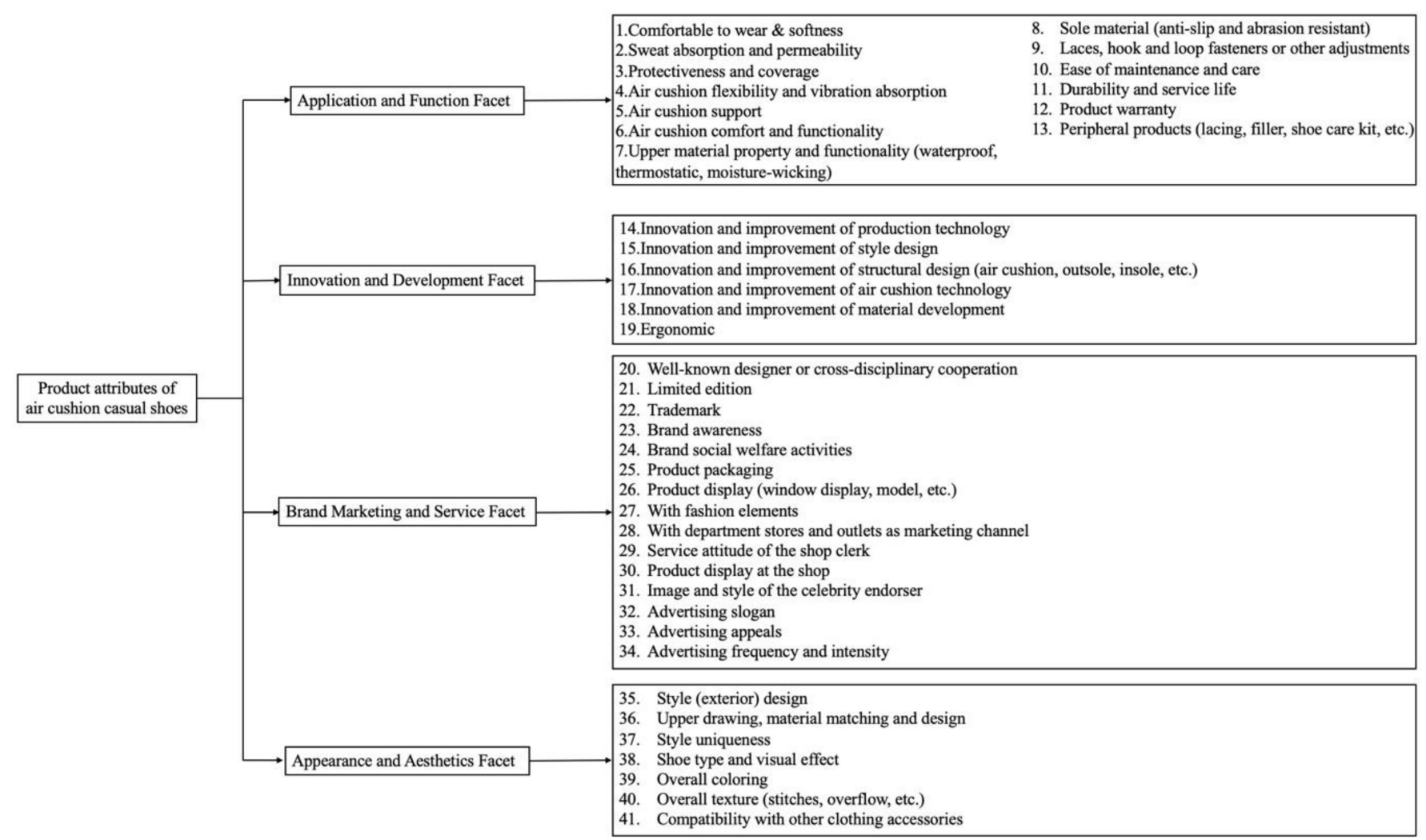

Figure 4. Forty-one product attributes in four categories of air-cushioned casual shoes for the SPD of this study.

\subsection{Questionnaire Survey with Kano's Two-Dimensional Quality Model}

The survey was carried out from 12-26 June 2020 with 217 questionnaires returned and 194 valid questionnaires (Tables 8 and 9).

\subsection{Kano's Two-Dimensional Quality Model}

The questionnaire survey adopted the "relative majority ratio" by Matzler and Hinterhuber (Table 10). According to this principle, the proportion of each Kano quality attribute was calculated for 41 attributes: 11 attributes of the one-dimensional quality, 2 of the required quality, and 28 of the different quality.

Table 8. Statistics of the questionnaire survey.

\begin{tabular}{cccc}
\hline & Off-Line & Online & Total \\
\hline Total number of returned questionnaires & 137 & 80 & 217 \\
\hline Invalid questionnaires & 17 & 6 & 23 \\
\hline Valid questionnaires & 120 & 74 & 194 \\
\hline Effective rate & $87.6 \%$ & $92.5 \%$ & $89.4 \%$ \\
\hline Period & \multicolumn{1}{c}{ 12-26 June 2020 for a total of 15 days } \\
\hline
\end{tabular}


Table 9. Demographics of questionnaire respondents.

\begin{tabular}{|c|c|c|c|}
\hline Basic Data & Item & Amount & Percentage Ratio \\
\hline \multirow{2}{*}{ Gender } & Male & 85 & 43.8 \\
\hline & Female & 109 & 56.2 \\
\hline \multirow{9}{*}{ Age } & Under 18 & 6 & 3.1 \\
\hline & From 19 to 25 & 54 & 27.8 \\
\hline & From 26 to 30 & 30 & 15.5 \\
\hline & From 31 to 35 & 29 & 14.9 \\
\hline & From 36 to 40 & 12 & 6.2 \\
\hline & From 41 to 45 & 22 & 11.3 \\
\hline & From 46 to 50 & 16 & 8.2 \\
\hline & From 51 to 55 & 16 & 8.2 \\
\hline & Over 56 & 9 & 4.6 \\
\hline \multirow{5}{*}{ Education } & Elementary school and below & 4 & 2.1 \\
\hline & Junior high school & 10 & 5.2 \\
\hline & Senior high school & 25 & 12.9 \\
\hline & College and university & 112 & 57.7 \\
\hline & Graduate school and above & 43 & 22.2 \\
\hline \multirow{9}{*}{ Occupation } & None & 3 & 1.5 \\
\hline & Student & 44 & 22.7 \\
\hline & Military and public servant & 49 & 25.3 \\
\hline & Agricultural industry & 2 & 1.0 \\
\hline & Business industry & 20 & 10.3 \\
\hline & Manufacturer & 25 & 12.9 \\
\hline & Service industry & 29 & 14.9 \\
\hline & Freelancer & 9 & 4.6 \\
\hline & Others & 13 & 6.7 \\
\hline \multirow{6}{*}{ Monthly income } & TWD 10,000 and below & 39 & 20.1 \\
\hline & TWD 10,000 30,000 & 53 & 27.3 \\
\hline & TWD 30,000 50,000 & 59 & 30.4 \\
\hline & TWD 50,000 70,000 & 17 & 8.8 \\
\hline & TWD 70,000 100,000 & 19 & 9.8 \\
\hline & TWD 100,000 and above & 7 & 3.6 \\
\hline
\end{tabular}


Table 10. Kano's quality classification of casual shoes with air-cushioned.

\begin{tabular}{|c|c|c|c|c|c|c|c|c|}
\hline \multirow[t]{2}{*}{ Facet } & \multirow[t]{2}{*}{ Attribute } & \multicolumn{6}{|c|}{$\begin{array}{c}\text { Proportion of Each Type of Kano Quality Attribute } \\
(\%)\end{array}$} & \multirow{2}{*}{$\begin{array}{l}\text { Classification } \\
\text { Attribute }\end{array}$} \\
\hline & & $\mathbf{A}$ & $\mathbf{O}$ & $\mathbf{M}$ & I & $\mathbf{R}$ & $\mathbf{Q}$ & \\
\hline \multirow{13}{*}{ 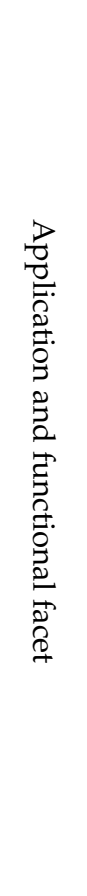 } & Comfortable to wear and softness & 14.90 & 37.60 & 23.70 & 23.10 & 0.00 & 0.15 & $\mathrm{O}$ \\
\hline & Sweat absorption and permeability & 10.30 & 34.00 & 24.80 & 31.10 & 0.00 & 0.50 & $\mathrm{O}$ \\
\hline & Protectiveness and coverage & 14.00 & 31.50 & 25.20 & 27.80 & 0.50 & 1.00 & $\mathrm{O}$ \\
\hline & $\begin{array}{l}\text { Air-cushioned flexibility and vibration } \\
\text { absorption }\end{array}$ & 19.10 & 34.50 & 20.00 & 25.80 & 0.70 & 0.50 & $\mathrm{O}$ \\
\hline & Air-cushioned support & 12.90 & 32.50 & 23.20 & 29.90 & 0.50 & 1.00 & $\mathrm{O}$ \\
\hline & Air-cushioned comfort and functionality & 13.90 & 33.50 & 24.20 & 27.80 & 0.00 & 0.00 & $\mathrm{O}$ \\
\hline & $\begin{array}{l}\text { Upper material property and functionality } \\
\text { (waterproof, thermostatic, moisture-wicking) }\end{array}$ & 21.10 & 24.70 & 16.50 & 37.00 & 0.00 & 0.50 & I \\
\hline & $\begin{array}{c}\text { Sole material (anti-slip and abrasion } \\
\text { resistant) }\end{array}$ & 19.60 & 26.30 & 29.90 & 22.70 & 1.70 & 0.50 & M \\
\hline & $\begin{array}{l}\text { Laces, hook and loop fasteners or other } \\
\text { adjustments }\end{array}$ & 20.60 & 18.00 & 16.50 & 44.20 & 0.50 & 0.00 & I \\
\hline & Ease of maintenance and care & 19.10 & 21.60 & 21.10 & 38.10 & 0.00 & 0.00 & I \\
\hline & Durability and service life & 19.10 & 31.90 & 20.00 & 26.80 & 0.50 & 1.50 & $\mathrm{O}$ \\
\hline & Product warranty & 14.90 & 17.00 & 18.60 & 46.90 & 2.50 & 0.00 & I \\
\hline & $\begin{array}{l}\text { Peripheral products (lacing, filler, shoe care } \\
\text { kit, etc.) }\end{array}$ & 12.90 & 16.00 & 15.50 & 49.70 & 5.60 & 0.00 & I \\
\hline \multirow{6}{*}{ 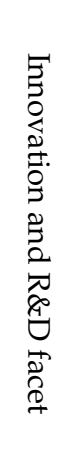 } & $\begin{array}{l}\text { Innovation and improvement of production } \\
\text { technology }\end{array}$ & 17.50 & 16.50 & 19.00 & 46.80 & 0.00 & 0.00 & I \\
\hline & Innovation and improvement of style design & 19.10 & 16.00 & 19.10 & 44.80 & 1.00 & 0.00 & I \\
\hline & $\begin{array}{l}\text { Innovation and improvement of structural } \\
\text { design (air-cushioned, outsole, insole, etc.) }\end{array}$ & 17.40 & 20.10 & 19.00 & 43.20 & 0.00 & 0.00 & I \\
\hline & $\begin{array}{l}\text { Innovation and improvement of } \\
\text { air-cushioned technology }\end{array}$ & 16.40 & 22.70 & 19.10 & 41.60 & 0.00 & 0.00 & I \\
\hline & $\begin{array}{l}\text { Innovation and improvement of material } \\
\text { development }\end{array}$ & 18.00 & 19.60 & 17.50 & 43.70 & 1.00 & 0.00 & I \\
\hline & Ergonomic & 15.90 & 37.10 & 22.10 & 24.20 & 0.00 & 0.50 & $\mathrm{O}$ \\
\hline \multirow{10}{*}{ 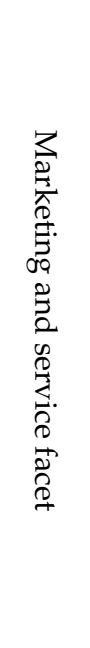 } & $\begin{array}{l}\text { Well-known designer or cross-disciplinary } \\
\text { cooperation }\end{array}$ & 16.00 & 3.10 & 8.20 & 67.60 & 4.90 & 1.00 & I \\
\hline & Limited edition & 16.50 & 1.50 & 4.70 & 65.40 & 10.80 & 1.00 & I \\
\hline & Trademark & 14.50 & 7.70 & 8.20 & 63.90 & 5.10 & 0.50 & I \\
\hline & Brand awareness & 22.60 & 5.70 & 9.80 & 57.10 & 4.00 & 0.50 & I \\
\hline & Brand social welfare activities & 14.90 & 9.80 & 12.80 & 58.70 & 3.50 & 0.00 & I \\
\hline & Product packaging & 13.40 & 15.50 & 20.10 & 48.40 & 2.50 & 0.00 & I \\
\hline & $\begin{array}{l}\text { Product display (window display, model, } \\
\text { etc.) }\end{array}$ & 18.00 & 8.80 & 10.30 & 59.70 & 3.00 & 0.00 & I \\
\hline & With fashion elements & 16.50 & 9.30 & 14.00 & 57.70 & 1.00 & 1.50 & I \\
\hline & $\begin{array}{l}\text { With department stores and outlets as } \\
\text { marketing channel }\end{array}$ & 17.00 & 10.80 & 5.10 & 62.80 & 3.50 & 0.50 & I \\
\hline & Service attitude of the shop clerk & 13.90 & 34.50 & 23.20 & 26.30 & 0.00 & 2.10 & $\mathrm{O}$ \\
\hline
\end{tabular}


Table 10. Cont.

\begin{tabular}{|c|c|c|c|c|c|c|c|c|}
\hline \multirow[t]{2}{*}{ Facet } & \multirow[t]{2}{*}{ Attribute } & \multicolumn{6}{|c|}{$\begin{array}{c}\text { Proportion of Each Type of Kano Quality Attribute } \\
(\%)\end{array}$} & \multirow{2}{*}{$\begin{array}{l}\text { Classification } \\
\text { Attribute }\end{array}$} \\
\hline & & A & $\mathbf{O}$ & $\mathbf{M}$ & I & $\mathbf{R}$ & $\mathbf{Q}$ & \\
\hline & Product display at the shop & 22.70 & 14.90 & 9.80 & 49.90 & 2.10 & 0.50 & I \\
\hline & Image and style of the celebrity endorser & 16.50 & 7.20 & 12.40 & 61.20 & 2.00 & 0.50 & I \\
\hline & Advertising slogan & 13.90 & 4.60 & 11.40 & 66.00 & 2.50 & 1.50 & I \\
\hline & Advertising appeals & 16.50 & 4.10 & 15.00 & 60.25 & 2.00 & 1.00 & I \\
\hline & Advertising frequency and intensity & 13.40 & 3.10 & 11.80 & 68.50 & 3.10 & 0.00 & I \\
\hline \multirow{7}{*}{ 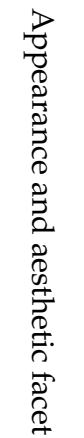 } & Style (exterior) design & 16.50 & 22.20 & 16.00 & 41.60 & 2.00 & 1.50 & I \\
\hline & $\begin{array}{l}\text { Upper drawing, material matching and } \\
\text { design }\end{array}$ & 13.40 & 23.20 & 17.50 & 43.30 & 1.50 & 1.00 & I \\
\hline & Style uniqueness & 19.00 & 18.60 & 16.00 & 43.20 & 1.50 & 1.50 & I \\
\hline & Shoe type and visual effect & 15.40 & 21.60 & 18.00 & 41.60 & 2.00 & 1.00 & I \\
\hline & Overall coloring & 15.10 & 24.20 & 21.10 & 36.50 & 1.50 & 1.00 & $\mathrm{O}$ \\
\hline & Overall texture (stitches, overflow, etc.) & 15.50 & 27.30 & 29.30 & 26.80 & 0.50 & 0.50 & M \\
\hline & Compatibility with other clothing accessories & 10.80 & 26.30 & 23.80 & 35.50 & 2.00 & 1.50 & $\mathrm{O}$ \\
\hline
\end{tabular}

Note: "A" stands for attractive quality, "O" stands for one-dimensional quality, " $\mathrm{M}$ " stands for must-be quality, "I" stands for different quality, and " $\mathrm{R}$ " stands for reverse quality.

\subsubsection{Attraction Quality}

The attractive quality is used as a tool to create product differentiation and reflects a consumer's desire for a specific product attribute. This attribute represents consumer satisfaction. The result of this study showed that consumers were not satisfied with but accepted "property and functionality of the upper in shoes (waterproof, thermostatic, moisture-wicking)" and "laces, hook and loop fasteners or other adjustments." Through the "brand awareness" and "comfort and style of the shop" in the category of marketing and service, consumers placed a high value on the product quality and commitment of a brand. The layout of the stores also seemed to affect the consumers' purchasing process. This suggests that the stores must do appropriate marketing activities to promote the brand images and raise recognition.

\subsubsection{One-Dimensional Quality}

The one-dimensional quality indicates the adequacy of quality for consumer satisfaction. The attributes of this quality are used as a basis for manufacturers to differentiate prices at the levels of products. For air-cushioned casual shoes, the attributes were related to the following:

(1) Application and function: "comfortable and softness to wear," "sweat absorption and permeability," "protectiveness and coverage," "flexibility and vibration absorption of air-cushions," "air-cushioned support," "comfort and functionality of air-cushions" and "durability and service life";

(2) Innovation and R\&D: "ergonomic";

(3) Brand marketing and service: "service attitude of the shop clerk";

(4) Appearance and aesthetics: "overall coloring" and "compatibility with other clothing accessories."

The customers considered the basic functionality to be important, which suggests that manufacturers must maintain and improve the one-dimensional quality attributes. The higher the price of the air-cushioned casual shoes, the more sufficient the product attributes must be, so the gap between the quality and price of the shoes is minimized. 


\subsubsection{Must-Be Quality}

This is the quality that manufacturers must provide for consumers. Manufacturers need to regard the must-be quality attributes when developing new products. The attributes included sole material (anti-slip and abrasion) in the category of application, and functional and overall texture (stitches and overflow) in the category of appearance and aesthetic. For these attributes, zero defects need to be achieved. Manufacturers need to exercise strict quality control and inspection.

\subsubsection{Indifferent Quality}

This had little effect on customer satisfaction. The customers were more satisfied with the improvement of the attributes in the category of application and functional rather than those of innovation and R\&D. Innovative improvements by $R \& D$ is a hidden attribute but necessary to improve the applicability and comfortability of the shoes to provide products of high quality and materials worth the price. The attributes such as a well-known designer or cross-disciplinary cooperation, limited edition, and advertising slogan in the category of marketing and service were not effective for improving the customers' satisfaction. The attributes in the category of appearance and aesthetics were more important for the consumers than those of marketing and service.

\subsubsection{Reverse Quality}

This study did not consider the reverse quality attribute in the analysis, and found that the consumers were not attracted to purchase a "limited edition" in the marketing and service facet.

\subsection{Consumer Satisfaction Index}

Kano's quality product attributes were classified as shown in Table 10. The consumer satisfaction coefficient with "consumer satisfaction index $\left(C S_{i}\right)$ " and "consumer dissatisfaction index $\left(C D_{i}\right)$ " was used to evaluate the degree of the customers' satisfaction and dissatisfaction with the attributes. The maximum coefficient was obtained by the weight calculation method by Sireli et al. [22]. The results provide information on how to meet the consumer demand (Table 11). In the coefficients and the quality scatter diagram [30], a total of 41 product attributes were classified into four quadrants as shown in Figure 5.

Table 11. Consumer satisfaction index of product attributes of air-cushioned casual shoes.

\begin{tabular}{|c|c|c|c|c|c|c|c|}
\hline Category & Attributes & $\begin{array}{l}\text { Quality Clas- } \\
\text { sification }\end{array}$ & $\mathrm{CS}_{\mathrm{i}}$ & $\mathrm{CD}_{\mathrm{i}}$ & $\begin{array}{l}\text { Weight of } \\
\text { Attribute }\end{array}$ & $\begin{array}{c}\text { Item } \\
\text { Ranking }\end{array}$ & $\begin{array}{l}\text { Category } \\
\text { Average }\end{array}$ \\
\hline \multirow{7}{*}{ 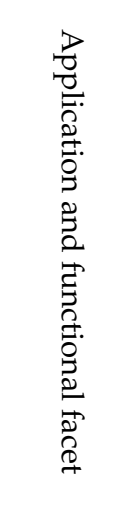 } & Comfortable to wear and softness & $\mathrm{O}$ & 0.529 & -0.617 & 0.617 & 1 & \multirow{7}{*}{0.504} \\
\hline & Sweat absorption and permeability & $\mathrm{O}$ & 0.442 & -0.587 & 0.587 & 4 & \\
\hline & Protectiveness and coverage & $\mathrm{O}$ & 0.462 & -0.576 & 0.576 & 6 & \\
\hline & $\begin{array}{l}\text { Air-cushioned flexibility and } \\
\text { vibration absorption }\end{array}$ & $\mathrm{O}$ & 0.539 & -0.548 & 0.548 & 10 & \\
\hline & Air-cushioned support & $\mathrm{O}$ & 0.461 & -0.565 & 0.565 & 9 & \\
\hline & $\begin{array}{l}\text { Air-cushioned comfort and } \\
\text { functionality }\end{array}$ & $\mathrm{O}$ & 0.477 & -0.580 & 0.580 & 5 & \\
\hline & $\begin{array}{l}\text { Upper material property and } \\
\text { functionality (waterproof, } \\
\text { thermostatic, moisture-wicking) }\end{array}$ & I & 0.461 & -0.415 & 0.461 & 17 & \\
\hline
\end{tabular}


Table 11. Cont.

\begin{tabular}{|c|c|c|c|c|c|c|c|}
\hline Category & Attributes & $\begin{array}{l}\text { Quality Clas- } \\
\text { sification }\end{array}$ & $\mathrm{CS}_{\mathrm{i}}$ & $\mathrm{CD}_{\mathrm{i}}$ & $\begin{array}{l}\text { Weight of } \\
\text { Attribute }\end{array}$ & $\begin{array}{c}\text { Item } \\
\text { Ranking }\end{array}$ & $\begin{array}{l}\text { Category } \\
\text { Average }\end{array}$ \\
\hline & $\begin{array}{l}\text { Sole material (anti-slip and } \\
\text { abrasion resistant) }\end{array}$ & M & 0.466 & -0.571 & 0.571 & 8 & \\
\hline & $\begin{array}{c}\text { Laces, hook and loop fasteners or } \\
\text { other adjustments }\end{array}$ & I & 0.389 & -0.347 & 0.389 & 27 & \\
\hline & Ease of maintenance and care & I & 0.031 & -0.427 & 0.427 & 14 & \\
\hline & Durability and service life & $\mathrm{O}$ & 0.521 & -0.531 & 0.531 & 11 & \\
\hline & Product warranty & I & 0.328 & -0.366 & 0.366 & 22 & \\
\hline & $\begin{array}{l}\text { Peripheral products (lacing, filler, } \\
\text { shoe care kit, etc.) }\end{array}$ & I & 0.307 & -0.335 & 0.335 & 28 & \\
\hline \multirow{6}{*}{ 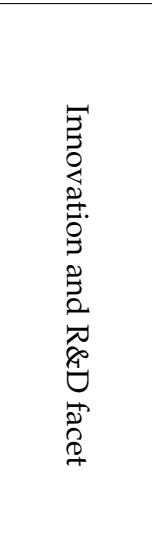 } & $\begin{array}{l}\text { Innovation and improvement of } \\
\text { production technology }\end{array}$ & $\mathrm{I}$ & 0.341 & -0.356 & 0.356 & 25 & \multirow{6}{*}{0.417} \\
\hline & $\begin{array}{l}\text { Innovation and improvement of } \\
\text { style design }\end{array}$ & I & 0.355 & -0.355 & 0.355 & 26 & \\
\hline & $\begin{array}{c}\text { Innovation and improvement of } \\
\text { structural design (air-cushioned, } \\
\text { outsole, insole, etc.) }\end{array}$ & I & 0.376 & -0.392 & 0.392 & 20 & \\
\hline & $\begin{array}{l}\text { Innovation and improvement of } \\
\text { air-cushioned technology }\end{array}$ & I & 0.392 & -0.419 & 0.419 & 15 & \\
\hline & $\begin{array}{l}\text { Innovation and improvement of } \\
\text { material development }\end{array}$ & I & 0.381 & -0.376 & 0.381 & 21 & \\
\hline & Ergonomic & $\mathrm{O}$ & 0.534 & -0.596 & 0.596 & 2 & \\
\hline \multirow{15}{*}{ 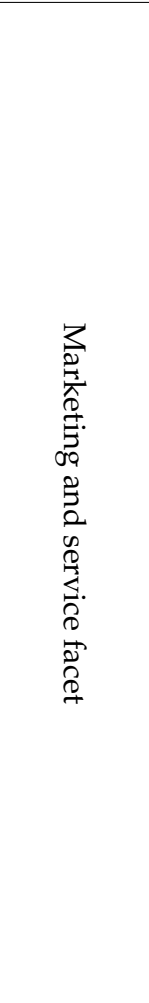 } & $\begin{array}{l}\text { Well-known designer or } \\
\text { cross-disciplinary cooperation }\end{array}$ & I & 0.201 & -0.119 & 0.201 & 40 & \multirow{15}{*}{0.279} \\
\hline & Limited edition & I & 0.204 & -0.070 & 0.204 & 41 & \\
\hline & Trademark & I & 0.235 & -0.169 & 0.235 & 35 & \\
\hline & Brand awareness & I & 0.297 & -0.163 & 0.297 & 38 & \\
\hline & Brand social welfare activities & I & 0.257 & -0.235 & 0.257 & 31 & \\
\hline & Product packaging & I & 0.297 & -0.366 & 0.366 & 23 & \\
\hline & $\begin{array}{l}\text { Product display (window display, } \\
\text { model, etc.) }\end{array}$ & I & 0.277 & -0.197 & 0.277 & 34 & \\
\hline & With fashion elements & I & 0.265 & -0.239 & 0.265 & 30 & \\
\hline & $\begin{array}{l}\text { With department stores and outlets } \\
\text { as marketing channel }\end{array}$ & I & 0.290 & -0.166 & 0.290 & 37 & \\
\hline & Service attitude of the shop clerk & $\mathrm{O}$ & 0.494 & -0.589 & 0.589 & 3 & \\
\hline & Product display at the shop & I & 0.386 & -0.254 & 0.386 & 29 & \\
\hline & $\begin{array}{c}\text { Image and style of the celebrity } \\
\text { endorser }\end{array}$ & I & 0.244 & -0.201 & 0.244 & 32 & \\
\hline & Advertising slogan & I & 0.193 & -0.167 & 0.193 & 36 & \\
\hline & Advertising appeals & I & 0.215 & -0.199 & 0.215 & 33 & \\
\hline & $\begin{array}{l}\text { Advertising frequency and } \\
\text { intensity }\end{array}$ & I & 0.170 & -0.154 & 0.170 & 39 & \\
\hline
\end{tabular}


Table 11. Cont.

\begin{tabular}{|c|c|c|c|c|c|c|c|}
\hline Category & Attributes & $\begin{array}{l}\text { Quality Clas- } \\
\text { sification }\end{array}$ & $\mathrm{CS}_{\mathrm{i}}$ & $\mathrm{CD}_{\mathrm{i}}$ & $\begin{array}{l}\text { Weight of } \\
\text { Attribute }\end{array}$ & $\begin{array}{c}\text { Item } \\
\text { Ranking }\end{array}$ & $\begin{array}{l}\text { Category } \\
\text { Average }\end{array}$ \\
\hline \multirow{7}{*}{$\begin{array}{l}\text { D } \\
0 \\
0 \\
0 \\
0 \\
0 \\
0 \\
0 \\
0 \\
0 \\
0 \\
0 \\
0 \\
0 \\
0 \\
0 \\
0 \\
0 \\
0 \\
0 \\
0 \\
0 \\
0\end{array}$} & Style (exterior) design & $\mathrm{I}$ & 0.402 & -0.397 & 0.402 & 19 & \multirow{7}{*}{0.454} \\
\hline & $\begin{array}{l}\text { Upper drawing, material matching } \\
\text { and design }\end{array}$ & I & 0.376 & -0.418 & 0.418 & 16 & \\
\hline & Style uniqueness & $\mathrm{I}$ & 0.388 & -0.357 & 0.388 & 24 & \\
\hline & Shoe type and visual effect & I & 0.383 & -0.410 & 0.410 & 18 & \\
\hline & Overall coloring & $\mathrm{O}$ & 0.406 & -0.467 & 0.467 & 13 & \\
\hline & $\begin{array}{l}\text { Overall texture (stitches, overflow, } \\
\text { etc.) }\end{array}$ & M & 0.433 & -0.572 & 0.572 & 7 & \\
\hline & $\begin{array}{l}\text { Compatibility with other clothing } \\
\text { accessories }\end{array}$ & $\mathrm{O}$ & 0.385 & -0.520 & 0.520 & 12 & \\
\hline
\end{tabular}

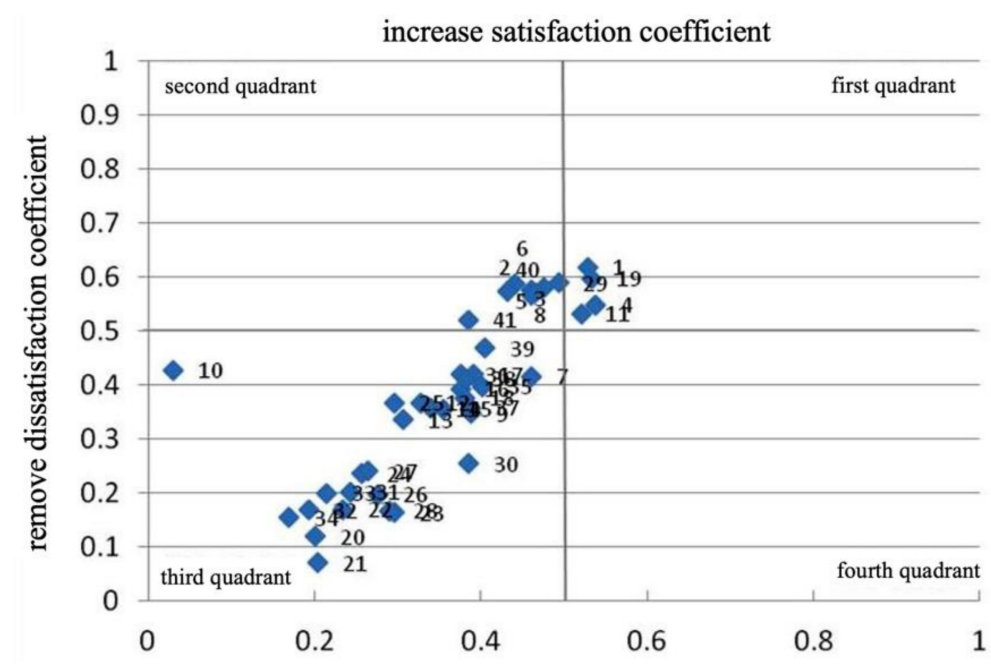

Figure 5. Product attribute coefficients in a quality scatter diagram.

The first quadrant of the scatter diagram has the product attributes of the onedimensional quality that increased the customers' satisfaction. Thus, manufacturers need to prioritize the improvement and implementation of the attributes in the first quadrant to improve consumer satisfaction. The attributes of the one-dimensional quality and must-be quality elements are found in the second quadrant. This indicates that the increase in satisfaction was smaller than that in dissatisfaction. Therefore, manufacturers need to improve the attributes in the second quadrant for reducing the customers' dissatisfaction. The third quadrant of the scatter diagram contains the product attributes of the must-be or one-dimensional quality. Manufacturers tend to invest fewer resources on the indifferent quality that relates to must-be or one-dimensional quality [22]. Therefore, manufacturers need to implement and consolidate the attributes of the one-dimensional, must-be, and attraction quality for the effective enhancement of consumer satisfaction.

We ranked the priorities of the product attributes based on the weights (Table 11). The average weights of the attributes in each category were the criteria for improving customer satisfaction. The weights became highest in the category of application and function and decreased in the categories of appearance and aesthetic, innovation and R\&D, and marketing and service, in that order (Figure 6). Therefore, manufacturers need to give priority to improving the product attributes in the category of application and function. Out of 41 product attributes, 19 product attributes showed higher weights than 0.4 . These attributes belonged to one-dimensional quality, must-be quality, and attractive quality. Thus, the relationship between foot anatomy (forefoot, sole, and arch of the foot) 
and comfort and functionality of air-cushions, air-cushioned support, and flexibility and vibration absorption of air-cushions must be considered in manufacturing air-cushioned casual shoes.

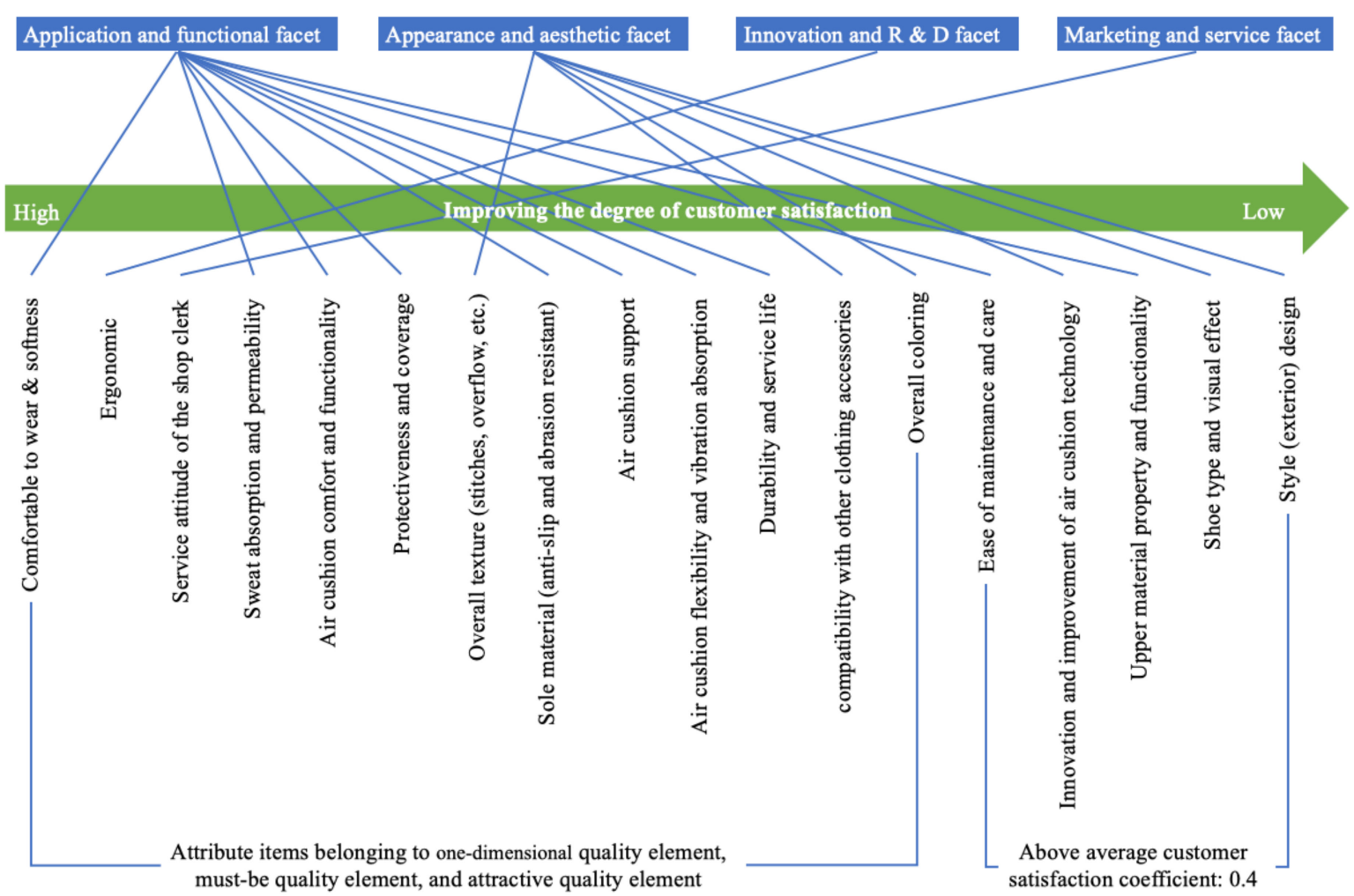

Figure 6. Prioritizing the improvement of product attribute to meet consumer satisfaction.

\subsection{Refined Kano's Two-Dimensional Quality Classification}

A refined Kano two-dimensional quality model was used to find out which attributes the customers considered to be important. The importance that the customers put on aircushioned casual shoes was used to classify eight items for the manufacturers to develop and improve. The product quality was classified with the criteria of the average score of 3.97 as shown in Table 12.

Table 12. Classification of the attributes in the refined Kano two-dimensional model of air-cushioned casual shoes.

\begin{tabular}{|c|c|c|c|c|c|}
\hline Facet & Attributes & Importance & Satisfaction & $\begin{array}{l}\text { Kano's Model } \\
\text { Quality } \\
\text { Classification }\end{array}$ & $\begin{array}{l}\text { Refined Kano's } \\
\text { Quality } \\
\text { Classification }\end{array}$ \\
\hline \multirow{8}{*}{ 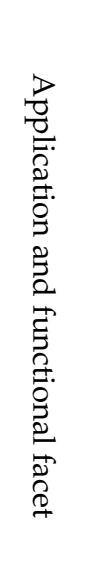 } & Comfortable to wear and softness & 4.73 & 4.22 & $\mathrm{O}$ & High value-added \\
\hline & Sweat absorption and permeability & 4.69 & 4.01 & $\mathrm{O}$ & High value-added \\
\hline & Protectiveness and coverage & 4.57 & 4.10 & $\mathrm{O}$ & High value-added \\
\hline & $\begin{array}{l}\text { Air-cushioned flexibility and vibration } \\
\text { absorption }\end{array}$ & 4.56 & 4.08 & $\mathrm{O}$ & High value-added \\
\hline & Air-cushioned support & 4.56 & 4.00 & $\mathrm{O}$ & High value-added \\
\hline & Air-cushioned comfort and functionality & 4.55 & 4.07 & $\mathrm{O}$ & High value-added \\
\hline & $\begin{array}{c}\text { Upper material property and } \\
\text { functionality (waterproof, thermostatic, } \\
\text { moisture-wicking) }\end{array}$ & 4.32 & 3.82 & I & Potential \\
\hline & $\begin{array}{l}\text { Sole material (anti-slip and abrasion } \\
\text { resistant) }\end{array}$ & 4.44 & 3.91 & $\mathrm{M}$ & Key \\
\hline
\end{tabular}


Table 12. Cont.

\begin{tabular}{|c|c|c|c|c|c|}
\hline Facet & Attributes & Importance & Satisfaction & $\begin{array}{l}\text { Kano's Model } \\
\text { Quality } \\
\text { Classification }\end{array}$ & $\begin{array}{l}\text { Refined Kano's } \\
\text { Quality } \\
\text { Classification }\end{array}$ \\
\hline & $\begin{array}{l}\text { Laces, hook and loop fasteners or other } \\
\text { adjustments }\end{array}$ & 3.93 & 3.74 & I & Care-free \\
\hline & Ease of maintenance and care & 4.18 & 3.84 & I & Potential \\
\hline & Durability and service life & 4.26 & 3.85 & $\mathrm{O}$ & High value-added \\
\hline & Product warranty & 4.03 & 3.65 & I & Potential \\
\hline & $\begin{array}{c}\text { Peripheral products (lacing, filler, shoe } \\
\text { care kit, etc.) }\end{array}$ & 3.08 & 3.57 & I & Care-free \\
\hline \multirow{6}{*}{ 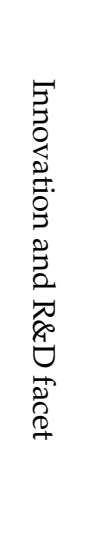 } & $\begin{array}{l}\text { Innovation and improvement of } \\
\text { production technology }\end{array}$ & 4.08 & 3.71 & I & Potential \\
\hline & $\begin{array}{l}\text { Innovation and improvement of style } \\
\text { design }\end{array}$ & 4.07 & 3.65 & $\mathrm{I}$ & Potential \\
\hline & $\begin{array}{l}\text { Innovation and improvement of } \\
\text { structural design (air-cushioned, outsole, } \\
\text { insole, etc.) }\end{array}$ & 4.16 & 3.83 & I & Potential \\
\hline & $\begin{array}{l}\text { Innovation and improvement of } \\
\text { air-cushioned technology }\end{array}$ & 4.19 & 3.76 & I & Potential \\
\hline & $\begin{array}{l}\text { Innovation and improvement of material } \\
\text { development }\end{array}$ & 4.16 & 3.78 & $\mathrm{I}$ & Potential \\
\hline & Ergonomic & 4.55 & 4.01 & $\mathrm{O}$ & High value-added \\
\hline \multirow{15}{*}{ 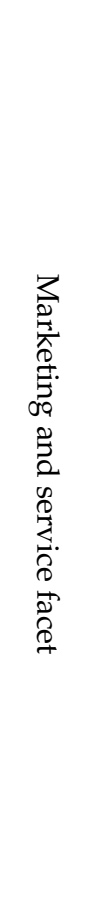 } & $\begin{array}{l}\text { Well-known designer or } \\
\text { cross-disciplinary cooperation }\end{array}$ & 3.21 & 3.26 & I & Care-free \\
\hline & Limited edition & 2.86 & 3.22 & I & Care-free \\
\hline & Trademark & 3.18 & 3.35 & $\mathrm{I}$ & Care-free \\
\hline & Brand awareness & 3.51 & 3.55 & I & Care-free \\
\hline & Brand social welfare activities & 3.59 & 3.45 & I & Care-free \\
\hline & Product packaging & 3.56 & 3.58 & I & Care-free \\
\hline & $\begin{array}{l}\text { Product display (window display, model, } \\
\text { etc.) }\end{array}$ & 3.42 & 3.45 & I & Care-free \\
\hline & With fashion elements & 3.67 & 3.34 & I & Care-free \\
\hline & $\begin{array}{l}\text { With department stores and outlets as } \\
\text { marketing channel }\end{array}$ & 3.51 & 3.52 & I & Care-free \\
\hline & Service attitude of the shop clerk & 4.38 & 3.92 & $\mathrm{O}$ & High value-added \\
\hline & Product display at the shop & 3.95 & 3.82 & I & Care-free \\
\hline & Image and style of the celebrity endorser & 3.57 & 3.60 & $\mathrm{I}$ & Care-free \\
\hline & Advertising slogan & 3.41 & 3.46 & I & Care-free \\
\hline & Advertising appeals & 3.56 & 3.47 & I & Care-free \\
\hline & Advertising frequency and intensity & 3.31 & 3.39 & I & Care-free \\
\hline
\end{tabular}


Table 12. Cont.

\begin{tabular}{|c|c|c|c|c|c|}
\hline Facet & Attributes & Importance & Satisfaction & $\begin{array}{c}\text { Kano's Model } \\
\text { Quality } \\
\text { Classification }\end{array}$ & $\begin{array}{c}\text { Refined Kano's } \\
\text { Quality } \\
\text { Classification }\end{array}$ \\
\hline \multirow{7}{*}{ 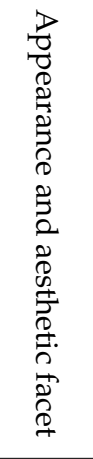 } & Style (exterior) design & 4.01 & 3.60 & $\mathrm{I}$ & Potential \\
\hline & $\begin{array}{l}\text { Upper drawing, material matching and } \\
\text { design }\end{array}$ & 4.10 & 3.59 & $\mathrm{I}$ & Potential \\
\hline & Style uniqueness & 4.01 & 3.52 & I & Potential \\
\hline & Shoe type and visual effect & 4.18 & 3.67 & I & Potential \\
\hline & Overall coloring & 4.27 & 3.76 & $\mathrm{O}$ & High value-added \\
\hline & Overall texture (stitches, overflow, etc.) & 4.33 & 3.86 & M & Key \\
\hline & $\begin{array}{l}\text { Compatibility with other clothing } \\
\text { accessories }\end{array}$ & 4.24 & 3.75 & $\mathrm{O}$ & High value-added \\
\hline & Average & 3.97 & 3.70 & & \\
\hline
\end{tabular}

\subsubsection{High and Low Attraction Quality}

The high attraction quality is the best tool to attract customers and its attributes can be used to improve consumer satisfaction, while manufacturers are advised to overlook the low attraction quality. Since there was no attraction quality in the analysis of this study, no element was classified in the refined Kano model.

\subsubsection{High Value-Added Quality}

The attributes of high value-added quality not only increase consumer satisfaction but also profits. Efforts are needed to implement the attributes. Eleven attributes of onedimensional quality of air-cushioned casual shoes were identified in the refined Kano model. Based on the average score of the importance, the following attributes of the onedimensional quality were regarded as those of the high value-added quality: wear and softness, sweat absorption and permeability, protectiveness and coverage, air-cushioned flexibility and vibration absorption, air-cushioned support, air-cushioned comfort and functionality, durability and service life, ergonomic, service attitude of store clerks, overall coloring, and compatibility with other clothing accessories. Therefore, the manufacturers need to develop the functionality of the air-cushioned casual shoes to improve consumer satisfaction and sales revenue.

\subsubsection{Low Value-Added Quality}

Low value-added quality hardly contributes to consumer satisfaction. However, the manufacturers must consider the attributes to avoid insufficient service and consumer dissatisfaction. None of the attributes was classified into the low value-added quality in the refined Kano model.

\subsubsection{Key Quality}

The key quality is essential for manufacturers to meet consumer demand. Shoe abrasion and slip resistance and overall texture (stitches and overflow) of the must-be quality in Kano's original model were classified into the key quality in the refined Kano model. Manufacturers need to consider this quality to satisfy consumers, which has important attributes that affect consumer's perceptions of air-cushioned casual shoes.

\subsubsection{Required Quality}

Manufacturers must provide the required quality to avoid causing consumer dissatisfaction. None of the elements in this study was classified as the required quality elements of the refined Kano model. 


\subsubsection{Potential Quality}

Several attributes of the potential quality belong and evolve into the attraction quality. Manufacturers need to consider the potential quality to attract consumers. The original Kano model had 12 attributes of the potential quality in the refined Kano model, they belonged to the innovation and development, and the appearance and aesthetics categories. The attributes were upper material property and functionality (waterproof, thermostatic, moisture-wicking), ease of maintenance and care, product warranty, innovation and improvement of production technology, innovation and improvement of style design, innovation and improvement of structural design (air-cushioned, outsole, insole), innovation and improvement of air-cushioned technology, innovation and improvement of material development, style (exterior) design, upper drawing, material matching, and design, style uniqueness, and shoe type and visual effect. Manufacturers must consolidate the attributes in the category of application and function as a short-term strategy and do research and development as a long term strategy to maintain the existing and future consumers.

\subsubsection{Care-Free Quality}

The refined Kano's model contained 16 attributes of the care-free quality in the category of marketing and service. Since air-cushioned casual shoes are functional footwear, the basic application and functional attributes need to be taken into consideration first, followed by marketing and promoting brands.

In brief, the refined Kano quality model has the following qualities in the order of importance: high value-added quality, key quality, and potential quality. Table 12 shows 11 attributes of the one-dimensional quality of Kano's original model are classified as those of the high value-added quality in the refined Kano model.

(1) The key quality is important to satisfy consumers. The attributes of the key quality are sole material (anti-slip and abrasion resistant) and overall texture (stitches, overflow).

(2) The attributes of the potential quality also belong to the attractive quality of Kano's original model. The attributes are upper material property and functionality (waterproof, thermostatic, moisture-wicking), ease of maintenance and care, product warranty, innovation and improvement of production technology, innovation and improvement of style design, innovation and improvement of structural design (aircushioned, outsole, insole), innovation and improvement of air-cushioned technology, and innovation and improvement of material development, style (exterior) design, upper drawing, material matching, and design, style uniqueness, and shoe type and visual effect. These attributes are considered as a strategy to attract potential consumers. The potential quality attracts the consumers who are concerned with the price.

(3) Care-free quality pertains to the marketing and service category of Kano's model. Since air-cushioned casual shoes are functional, it is required for manufacturers to consider the comfort and performance of developing value-added products.

\section{Conclusions}

The traditional shoe industry has consumed a lot of energy and resources, such as fossil fuels, rubber, cotton, and toxic materials. The introduction of SPD helps the industry save energy and resources as it allows manufacturers to focus on specific product attributes, which increases revenue as well as consumer satisfaction with appropriate design, functions, and recycling materials. For proposing an SPD model for the shoe industry, Kano's twodimensional model was adopted with interviews and questionnaire surveys.

The interview with experts with careers in the shoe industry contributed to selecting product attributes of an air-cushioned casual shoe company that were chosen as the research subject. Taiwan's small and medium-sized shoe manufacturers are experiencing the transformation to sustainable development. For the development, brand management and satisfying customer demand are major challenges as long as the past development process 
and marketing are maintained. An appropriated SPD model with the product attributes provides the basis to improve consumer satisfaction and brand image to enable the shoe industry to develop continuously and strategically. In the shoe industry, functionality from the ergonomic aspect in innovation and R\&D and design for overall color matching and matching with other clothing accessories are important factors to greatly increase consumer satisfaction and reduce dissatisfaction.

Therefore, this study suggests the way to define and select the product attributes with which manufacturers understand consumer demand and target market. For the air-cushioned casual shoes, the refined Kano model allowed to reveal that wear-resistant and non-slip sole and overall texture (stitch, overflow) were important attributes for the customers to purchase the shoes. In terms of innovation and R\&D and marketing and service, it indicated that the shoe manufacturers need to focus on innovation in technology and materials.

The product attributes that were defined by the model to stimulate consumers' desire to purchase will help the manufacturers define marketing strategies. When air-cushioned casual shoes on the market are similar in terms of design and function, the result of the refined Kano model recommends that manufacturers respond actively to different demands from various age groups and focus on highlighting the difference from competing products. A new method with the refined Kano model provides a way to define the SPD model with product attributes that enable the sustainable development of the industry by establishing a product attribute framework to improve consumer satisfaction for practical applicability. The SPD model is applied to an industry that has limited resources but needs sustainable development. It also helps to determine the demanded qualities for improving consumer satisfaction, which allows manufacturers to maintain sustainable product development.

Funding: This work was supported by the Ministry of Science and Technology of the Republic of China under grant MOST 108-2628-E-029-001-MY3.

Institutional Review Board Statement: The study did not require ethical approval.

Informed Consent Statement: Informed consent was obtained from all subjects involved in the study.

Data Availability Statement: The data are not publicly available due to data belonging to the company's internal professional managers.

Conflicts of Interest: The authors declare no conflict of interest.

\section{References}

1. Jaghbeer, Y.; Hallstedt, S.I.; Larsson, T.; Wall, J. Exploration of simulation-driven support tools for sustainable product development. Procedia Cirp 2017, 64, 271-276. [CrossRef]

2. Stark, R.; Buchert, T.; Neugebauer, S.; Bonvoisin, J.; Finkbeiner, M. Benefits and obstacles of sustainable product development methods: A case study in the field of urban mobility. Des. Sci. 2017, 3, e17. [CrossRef]

3. Ahmad, S.; Wong, K.Y.; Tseng, M.L.; Wong, W.P. Sustainable product design and development: A review of tools, applications and research prospects. Resour. Conserv. Recycl. 2018, 132, 49-61. [CrossRef]

4. Gordon, M.; Musso, C.; Rebentisch, E.; Gupta, N. Businesses with the best product-development track records stand apart from their less-successful peers in three crucial ways. In The Path to Successful New Products; McKinsey Quarterly: Seattle, WA, USA, 2010 .

5. Ishioka, M.; Yasuda, K. Product development concept with product sustainability. In Proceedings of the PICMET'09-2009 Portland International Conference on Management of Engineering \& Technology, Portland, OR, USA, 2 August 2009; pp. 1699-1706.

6. Park, C.W.; Jaworski, B.J.; Maclnnis, D.J. Strategic brand concept-image management. J. Mark. 1986, 50, 135-145. [CrossRef]

7. Richardson, P.; Dick, A.S.; Jain, A.K. Extrinsic and intrinsic cue effects on perceptions of store brand quality. J. Mark. 1994, 58, 28-36. [CrossRef]

8. Reynolds, T.J.; Gutman, J. Advertising as image management. J. Advert. Res. 1984, 24, 27-38.

9. Hsu, C. Determinants of mature traveler's motorcoach tour satisfaction and brand loyalty. J. Hosp. Tour. Res. 2000, 24, 223-238. [CrossRef]

10. Anderson, E.W.; Sullivan, M.W. The antecedents and consequences of consumer satisfaction for firms. Mark. Sci. 1993, 12, 124-143. [CrossRef] 
11. Huiskonen, J.; Pirttila, T. Sharpening logistic consumer service strategy planning by applying Kano's quality element classification. Int. J. Prod. Econ. 1998, 56, 253-260. [CrossRef]

12. Kotler, P.; Gartner, D. Country as brand, product, and beyond: A place marketing and brand management perspective. J. Brand Manag. 2002, 9, 249-261. [CrossRef]

13. Kano, N.; Seraku, N.; Takahashi, F.; Tsuji, S. Attractive quality and must-be quality. Qual. Control Mon. 1984, 41, 39-48.

14. Yang, C.C. The refined kano's model and its application. Total Qual. Manag. 2005, 16, 1127-1137. [CrossRef]

15. Yoji, A. New Product Development-Practical Application of Quality Functions; China Productivity Center: New Taipei, Taiwan, 1992.

16. Jane, A.C.; Dominguez, S.M. Citizens role in health services: Satisfaction behavior: Kano's model, Part2. Qual. Manag. Health Care 2003, 12, 72-80. [CrossRef]

17. Joiner, B.L. Fourth generation management: The new business consciousness. Acad. Manag. Perspect. 1994, 8, 118-119. [CrossRef]

18. Vasilash, G.S. Attractive quality: Getting it can help. Production 1995, 107, 64-65.

19. Tan, K.C.; Pawitra, T.A. Integrating SERVQUAL and Kano's Model into QFD for service excellence development. Manag. Serv. Qual. 2001, 11, 418-430. [CrossRef]

20. Schvaneveldt, S.; Takao, E.J.; Masami, M. Consumer evaluation perspective of service quality: Evaluation factors and two-way model of quality. Total Qual. Manag. 1991, 2, 149-161. [CrossRef]

21. Matzler, K.; Hinterhuber, H.H. How to make product development projects more successful by integrating Kano's model of consumer satisfaction into quality function deployment. Technovation 1998, 18, 25-38. [CrossRef]

22. Sireli, Y.; Kauffmann, P.; Ozan, E. Integration of Kano's model into QFD for multiple product design. IEEE Trans. Eng. Manag. 2007, 54, 380-390. [CrossRef]

23. Lu, T.J.; Juan, Y.K. Applying kano two-dimensional quality model to build the performance evaluation indicators of long-life high-quality condominiums. Sustainability 2019, 11, 4046. [CrossRef]

24. Zhang, X.; Li, J.; Hu, Z.; Qi, W.; Zhang, L.; Hu, Y.; Su, H.; Ferrigno, G.; Momi, E.D. Novel design and lateral stability tracking control of a four-wheeled rollator. Appl. Sci. 2019, 9, 2327. [CrossRef]

25. Tu, J.C.; Yang, C.H. Consumer needs for hand-touch product designs based on the experience economy. Sustainability 2019, 11, 2064. [CrossRef]

26. Wu, J.; Wang, Y.; Zhang, R.; Cai, J. An approach to discovering product/service improvement priorities: Using dynamic importance-performance analysis. Sustainability 2018, 10, 3564. [CrossRef]

27. Chen, K.L.; Yeh, T.M.; Pai, F.Y.; Chen, D.F. Integrating refined Kano's model and QFD for service quality improvement in healthy fast-food chain restaurants. Int. J. Env. Res. Public Health 2018, 15, 1310. [CrossRef] [PubMed]

28. Min, H.; Yun, J.; Geum, Y. Analyzing dynamic change in consumer requirements: An approach using review-based kano analysis. Sustainability 2018, 10, 746. [CrossRef]

29. Qiu, H.Z. Structural Equation Model (LISREL's Theory, Technology and Application); Shuang Yeh Publications: Taipei, Taiwan, 2003.

30. Qianli, X.; Roger, J.J.X.Y.; Helander, M. An analytical Kano's model for consumer need analysis. Des. Stud. 2009, 30, 87-110. 